SECTION 5

Perspectives on the Dutch Atlantic 
Pieter C. Emmer - 9789004271319

Downloaded from Brill.come4/26/2023 12:53:24PM via free access 


\title{
The Rise and Decline of the Dutch \\ Atlantic, 1600-1800
}

\author{
Pieter C. Emmer
}

\section{Introduction}

The Dutch Republic has sometimes been coined "a miracle." It stood out among the nations of the world because of its large trading empire in Europe, Asia and the Atlantic. Around 1650, the Dutch share in world trade might well have been larger than that of any other nation in Europe and, indeed, in the world. Over time, however, the Dutch were surpassed by their rivals, notably Britain and France, countries with more people and money in addition to their superior military and naval might. In retrospect, it seems a miracle indeed that the Dutch were able to build such a large trade network considering the relatively small size of the Dutch population and its limited resources.

In the past decades, however, the duration of the primacy of Dutch trade in the Atlantic has been questioned. It now seems that the trade between the Atlantic powers in Europe with their respective colonies was mainly in the hands of the national merchant communities, that the Dutch were able to break through these national barriers, but were driven out earlier than previously has been assumed, even in those areas of the Atlantic where protective legislation did not exist or could be evaded. Usually, the relative decline of Dutch commerce in the Atlantic has been explained by the fact that rival nations excluded Dutch traders from their colonies by applying protective legislation. This contribution explores the possibility that the declining competitiveness of Dutch trade and shipping constituted an additional cause for the slow erosion of the Dutch share in the early modern Atlantic economy. Over time, it became the most important barrier to the Dutch maritime activities. During the first half of the nineteenth century, only the relative inefficiency of the Dutch merchant marine can explain why it was in need of protective legislation governing the maritime trade routes to and from the Dutch colonies in East and West in order to survive in the face of British and American competition.

* A section of this contribution has been published as P.C. Emmer, "The Dutch and the Atlantic Challenge, 1600-1800," in A 'Deus ex Machina' Revisited. Atlantic Colonial Trade and European Development, ed. P.C. Emmer, O. Pétré-Grenouilleau and Jessica Vance Roitman (Leiden: Brill, 2006), 151-77.

(C) PIETER C. EMMER, 2014 | DOI 10.1163/9789004271319_015

This is an open access chapter distributed under the terms of the Creative Commons 


\section{The Dutch in the Early Atlantic}

The beginnings of the Dutch expansion in the Atlantic were impressive. During the initial phase between 1580 and 1650, Dutch merchants started to send their ships to all corners of the world. The Dutch were able to make important inroads into the Iberian trading networks in Asia and the Atlantic, and they conquered one of the most promising parts of the New World, Pernambuco, with its rapidly expanding sugar production. In addition, they took possession of a sizeable part of North America as well as of several small enclaves on the Coast of West Africa and a number of small islands in the Caribbean, some of which were developed into important commercial hubs. In spite of this flurry of activity, after $165^{\circ}$ the two largest Dutch colonies were lost in rapid succession, in addition to which Dutch ships encountered an increasing number of trade barriers due to the protectionist legislation of its commercial rivals. These developments reduced the Dutch share in Atlantic trade and shipping to less than 10 percent, much lower than their share in the intra-European trade and in the trade between Europe and Asia. ${ }^{1}$

There are two possible explanations for this decline. Most frequently, historians of the early Dutch overseas expansion point to the fact that the Netherlands was only a small country, that military and naval superiority might not have been of decisive importance when trading in Europe and Asia, but that it did make a difference in the Atlantic, where the Dutch were unable to match the resources of the larger powers. Also, in contrast to Asia, colonists were an important component of the expansion of Europe in the Atlantic, and the larger countries were in a much better position than the relatively small population of the Dutch republic to send migrants overseas.

During the past decades, however, some of the traditional explanations of the modest Dutch performance in the Atlantic have been challenged. Rather than blaming the rival powers for cutting the Dutch down to size, it might well have been possible that the Dutch share in the Atlantic commerce did not increase at the same pace as that of the other Atlantic powers because of internal factors such as the decline in the competitiveness of Dutch shipping, the low return on Dutch investments in the Atlantic or the lackluster attempts at sending European - not necessarily Dutch - colonists to the settlement colonies, thus foregoing the opportunity to create a transatlantic market for Dutch goods and services.

1 Wim Klooster, "An Overview of Dutch Trade with the Americas" in Riches from Atlantic Commerce. Dutch Transatlantic Trade and Shipping, 1585-1817, ed. Johannes Postma and Victor Enthoven (Leiden and Boston: Brill, 2003), 365-384, 382. 
In spite of these new arguments stressing the internal causes of the relatively modest Dutch participation in Atlantic trade and migration, there are still many reasons to support the contention that external forces such as the military, naval and demographic superiority of the larger nations in the Atlantic forced the Dutch to play a marginal role. The Spanish exclusion policies, the English Navigation Acts and the protectionist legislation in France, all backed up by an impressive naval presence, seem to confirm that the declining role of the Dutch in the Atlantic was indeed the result of external forces. This is not to say, of course, that the Dutch did not play a role in these empires, as the works of Silvia Marzagalli and Ana Crespo Solano for the French and Spanish, respectively, show in this volume. Had the Spanish, Portuguese, English, and French colonists been allowed to choose, they would have preferred to trade with the Dutch rather than with their own merchants. This is a point made in Christian Koot's contribution to this book for the English in the Chesapeake during the seventeenth and early eighteenth centuries. During the first phase of Dutch expansion into the Atlantic, Dutch traders were known all over to offer lower freight rates and a better array of trade goods at lower prices than any of their competitors. That seems to suggest that external forces limited the Dutch expansion in the Atlantic. ${ }^{2}$

A case in point in the traditional historiography is the conquest and loss of Dutch Brazil. The Dutch could not defend this colony as they were attacked from within as well as from outside for the simple reason that there were too few Dutch colonists, with the result that the Portuguese remained a disloyal majority and a permanent safety hazard for the Dutch colonial administrators. ${ }^{3}$ Only in West Africa were the Dutch able to hold their ground for the simple reason that military or naval superiority had little effect on the presence of the various European nations there due to the extremely high mortality rate among European crews and troops. The relatively important Dutch presence on the African Coast, where no outside power could dominate the others, seems to confirm the view that the Dutch could have achieved much more in the Atlantic had it been a more level playing field.

Over the past decades, however, new research seems to suggest that the various foreign protectionist policies were not the sole cause of the modest performance of the Dutch in the Atlantic, but that the decreasing competitiveness of Dutch shipping also played a part. Even in those areas and during those periods, where and when free competition in the Atlantic was possible, the

\footnotetext{
2 Jonathan I. Israel, Dutch Primacy in World Trade, 1585-1740 (Oxford: Clarendon, 1989), 208-209.

3 C.R. Boxer, The Dutch in Brazil, 1624-1654 (Hamden, Conn.: Archon, 1973), 159-203.
} 
Dutch commercial performance seemed far less competitive than has been assumed previously.

A case in point is the volte-face in the explanation of the rapid rise in the number of enslaved Africans on the island of Barbados during the period between 1640 and 1660 , when the planters there changed from cultivating tobacco to sugar cane. Until recently, the only explanation for the rapid rise in the number of slaves on Barbados took the dominant position of the Dutch slave traders on the island for granted. After the loss of their slave market in Brazil, the Dutch had a fully developed slave trading system in place, but no customers. Keen to create "a second Brazil," the Dutch slavers lowered their prices, making slavery more affordable for the Barbadian planters relative to the costs of importing indentured laborers from England and Ireland. Similarly, the ubiquitous Dutch traders were credited with being almost the sole suppliers of slaves to the French islands, where the transition from tobacco to sugar cane took place a few decades later than in the English Caribbean. It was assumed that until the third quarter of the seventeenth century the English and French slave traders could not compete with their Dutch rivals.

Recently, however, the explanation for the rapid rise in the number of slaves on Barbados in the decade between 1650 and 1660 has been turned upside down. It now seems that there were a sufficient number of English slave traders to provision Barbados with enslaved Africans right from the beginning of sugar cultivation on the island. True, in ${ }_{16} 5_{1}$ Cromwell proclaimed the first set of Navigation Acts that prohibited the colonists on Barbados from buying slaves from foreign ships. Yet, these laws would not have been enacted had the English slave trade been ineffective and almost non-existent as has been previously assumed. ${ }^{4}$ This seems to suggest that the Dutch competitiveness in the early slave trade to the Caribbean had been far less impressive than had been previously assumed and that the English slave traders had been able to compete with the Dutch even before English colonial trade became protected.

For a later period in the seventeenth century Atlantic, similar doubts can be raised about the competitiveness of the Dutch merchant marine. After the reconquest of Dutch Brazil by the Portuguese in 1654, the shipping capacity of the Portuguese and Brazilian merchant fleets remained inadequate and it seemed that not Dutch, but English ships filled that gap. ${ }^{5}$ The same applied to Spanish America, where the Dutch had to surrender part of their - illegal trade to British interlopers. During the second half of the eighteenth century,

4 Russell R Menard, Sweet Negotiations: Sugar, Slavery, and Plantation Agriculture in Early Barbados (Charlotteville, Va.: University of Virginia Press, 2006), 59.

5 Boxer, The Dutch in Brazil, 251. 
Dutch competitiveness in trade and shipping in the Atlantic seemed to have declined even more as the British, French, American and even Danish slave traders became heavily involved in the slave trade to Cuba, but not the Dutch.

As far as migration goes, the same situation applies. The Dutch could have put more effort into recruiting colonists for their settlement colonies in North and South America. No rival power could have prevented this as demonstrated by the very successful recruitment policies of the Dutch East India Company, each year luring thousands of young men from all over Europe to risk their lives in the tropical parts of Asia with less than an even chance of returning home. Rather than using their recruitment system to send migrants to the Dutch settlement colonies, the Dutch merchants only became involved in the transport of mainly German migrants to the British settlement colonies. The Dutch merchant community was not interested in investing in "planting ventures." It could be argued that Dutch merchants and capital owners rather invested in ventures that yielded higher profits than sending migrants to the colonies and that English merchants were more inclined to invest in migration as they might have had fewer alternatives for investment. In reality, however, the investment opportunities of the two nations hardly differed and that seems to suggest that the English mercantile community had a better eye for long-term economic growth in the Atlantic than their Dutch counterparts.

\section{The British and Dutch Compared ${ }^{7}$}

The unwillingness of the Dutch merchant community to invest more in naval power and migration made the Dutch into the Atlantic losers of the eighteenth

6 Nicholas Canny, "English Migration into and across the Atlantic during the Seventeenth and Eighteenth Centuries," in Europeans on the Move: Studies on European Migration, 1500-1800, ed. Nicholas Canny (Oxford: Oxford University Press, 1994), 39-75; T.C. Smout, N.C. Landsman, and T.M. Devine, "Scottish Emigration in the Seventeenth and Eighteenth Centuries," Europeans on the Move, 76-112; L.M. Cullen, "The Irish Diaspora of the Seventeenth and Eighteenth Centuries" Europeans on the Move, 113-152; and Nicholas Canny, "In Search of a Better Home? European Overseas Migration, 1500-1800," Europeans on the Move, 263-283.

7 Why compare the British and the Dutch and not, for instance, the Dutch and the Portuguese? The Portuguese case would seem to have offered a more obvious counterpoint to the Dutch example, considering that both powers had a small geographical territory on the European continent and a relatively small population inhabiting this territory. Unfortunately, however, the state of the historiography regarding Portuguese economic history makes it impossible to identify the exact differences with Dutch trade history. Moreover, the Portuguese did not have a large mercantile shipping network in Europe like the British, the French and the 
century. In fact, "a big divide" showed up when comparing the Atlantic achievements of Britain and the Netherlands. Britain became the only European country to which the Atlantic made a difference during both the eighteenth and nineteenth centuries. After 1750, Britain's quantum leap forward in the volume of exports to the Caribbean and North America was unique.

In the eighteenth century, Britain's Atlantic trade surpassed its European commercial activities. In 1700, 67 percent of British imports came from Europe and 23 percent from North America, the Caribbean, Africa and the East Indies. By $175^{\circ}$, these percentages were 55 percent and 45 percent respectively, and in the years just before 1800,42 percent and $5^{8}$ percent. In absolute numbers, the value of all overseas trade had quadrupled: from nearly 6 million pounds in 1700 , surpassing nearly 8 million pounds in 1750, to nearly 24 million pounds during the last years of the eighteenth century. The story of British exports looked very similar: in 1700,85 percent of these exports went to Europe, in 1750, 77 percent and in 1800, 30 percent. The value of British exports increased from 4.5 million pounds in 1700 to 18 million pounds around 1800. These figures indicate that the shift towards the Atlantic took place between $175^{\circ}$ and 1800 , and that Britain's most dynamic Atlantic trading partners were the West Indies and North America, whose share in the export of British domestically-made products, rose from 11 percent in 1700 to an impressive $5^{6}$ percent just before 1800.8

The Dutch, on the other hand, remained more oriented toward trade within Europe, in spite of a modest shift towards the Atlantic during the second half of the eighteenth century. Of the 100 ships leaving Dutch ports between 1600 and 1800 on average about 80 had destinations in Europe and the Mediterranean, five sailed to Asia, and 15 ships had Atlantic destinations, a conclusion mirrored in Silvia Marzagalli's sample for 1780 which is presented in this volume. In the second half of the eighteenth century the Atlantic offered more opportunities for economic growth than Europe and Asia as reflected in the sharp increase in British and French trade in the Atlantic. ${ }^{9}$ The modest

Dutch. Because of this, the Portuguese had to trade in the wider Atlantic, as they had no other alternative. These reasons make a comparison with the Dutch not a very attractive or fruitful endeavor at present.

8 Kenneth Morgan, Slavery, Atlantic Trade and the British Economy, 1600-180o (Cambridge: Cambridge University Press, 200o), 19 (table).

9 G. Daudin, "Do Frontiers Give or do Frontiers Take? The Case of Intercontinental Trade in France at the End of the Eighteenth Century," in A 'Deus ex Machina' Revisited. Atlantic Colonial Trade and European Development, ed. P.C. Emmer, O. Pétré-Grenouilleau and Jessica Vance Roitman, 199-224. 
increase of the Dutch commercial activities in the Atlantic during that period is testimony to the growing relative inefficiency of Dutch shipping and trade.

The divergence of the Dutch and British experience in the Atlantic began at home. Economic growth in the Netherlands peaked between 1580 and 1620 . After 1670 , a period of stagnation set in, lasting for about two centuries. When economic growth in the Atlantic increased during the eighteenth century, the Netherlands had a stagnating economy at home. No wonder Adam Smith, writing in 1776 , was of the opinion that the Netherlands had "acquired the full complement of riches which the nature of its soils and climate and its situation with respect to other countries, allowed it to acquire." The Netherlands had accumulated so much capital that profits were driven close to zero, and the Dutch economy could advance no further. ${ }^{10}$ This led to the phenomenon mentioned in Kenneth Morgan's contribution to the volume. The Dutch began to invest heavily in British state bonds, in part because there were limited investment opportunities to be had at home.

Let there be no misunderstanding: the results of the early and short-lived period of growth in the Netherlands between 1575 and 1675 were impressive, even by modern standards. The Netherlands was the first country to break the trend of declining real wages caused by rising populations and rising prices. After 1580 , a widening difference between the real wages in the Netherlands and England developed that lasted into the middle of the eighteenth century. During the first half century after 1575, when the growth spurt set in, the nominal wage for unskilled labor increased from 0.28 guilders to 0.73 guilders. As prices rose much more slowly, the increase in buying power was at least $5^{\circ}$ percent. That explains why the Netherlands was flooded with migrant laborers from abroad. There was little danger that these migrant laborers would bring down wages since they were easily absorbed into the labor force as the demand for labor was rising rapidly, in spite of the opinion of Karl Marx that the Dutch Republic was the "model capitalist nation of the seventeenth century" and, thus, that "by 1648 the people of Holland [were] more overworked, poorer, and more brutally oppressed than those of all the rest of Europe put together."11

The economic miracle at home took place well before economic opportunities in the wider Atlantic became attractive to the Dutch. The Dutch share in

10 Jan de Vries, "Dutch Economic Growth in Comparative-Historical Perspective, 1500-2000," De Economist 148, no. 4 (2000): 443-467, citation Smith, 451.

11 Jan Lucassen, "Mobilization of Labour in Early Modern Europe," in Early Modern Capitalism. Economic and Social Change in Europe, 1400-1800, ed. Maarten Prak (London: Routledge, 2001), 161-174, 162. 
the Atlantic plantation production was modest at best and never sufficient to provide more than half the sugar processed in the Netherlands. After the failed attempt at conquering part of Portuguese Brazil, the Dutch acquired a major plantation colony in the New World by taking Suriname from the English in 1667. In addition, the Dutch took possession of some smaller neighboring plantation colonies in the same region on the coast of South America between the Amazon and Orinoco rivers. During the first 150 years the Dutch plantation colonies did increase their output, but none saw the dramatic upswing in the production of sugar and cotton that occurred in some of the other Caribbean colonies.

After the beginning of the Fourth Anglo-Dutch War (1780-1784), the differences between the Dutch and the British economies in the Atlantic became even more pronounced. During the last two decades of the eighteenth century, Britain saw its trade in the Atlantic, both in slaves and goods, grow more rapidly than its trade to other destinations, while the Dutch experienced a decline in their Atlantic trade, with the Dutch slave trade coming to a virtual standstill. The GDP per capita in the Netherlands peaked around $165^{\circ}$ and declined somewhat during the following 200 years, while between 1500 and 1700 the GDP per capita in England was much lower than that of the Netherlands, but almost doubled during the period 1700-1820. The same development occurred in European shipping. The Dutch share is estimated to have been 40 percent in $165^{\circ}$ and 12 percent in 1780; the British share grew from 12 percent to 26 percent. ${ }^{12}$ Both countries saw the percentage of trade outside of Europe increase, but the reasons for this shift were very different.

In the case of the $\mathrm{UK}$, the reorientation was caused by the Industrial Revolution that encouraged the exportation of manufactured goods in exchange for the importation of foodstuffs and raw materials. The "Agricultural Revolution" in the UK allowed the country to double its population during the eighteenth century. The Netherlands, on the other hand, experienced a very slow increase in its population and did not industrialize until late in the nineteenth century. The increasing share of colonial products in Dutch trade was not a reflection of a new and innovative home economy but, rather, of the opposite. It indicated that the Dutch had become less competitive in Europe and that they had to retreat to an area where part of their trade was protected by mercantilist legislation. Even so, the Dutch share in the total volume of the trade in plantation crops declined. The value added in this trade was limited,

12 Jan Luiten van Zanden, "Early Modern Economic Growth. A Survey of the European Economy, 1500-180o," in Early Modern Capitalism, ed. Maarten Prak, 69-88, 76 (Table 4.3), 82 (Table 4.4). 
and the colonial products were not paid for by new Dutch manufactures, but by traditional goods partly imported from Asia.

Britain, on the other hand, saw its export to North America triple between $175^{\circ}$ and 1800 , and the export of British domestic products to the West Indies increased five times during these 50 years. This seems to suggest that the early mechanization of British industry did help to increase Britain's Atlantic trade as only merchants from that country could offer an array of goods that catered to the increasing purchasing power of the consumers in the wider Atlantic. Textiles are a case in point because only Britain could provide a mix of textiles that were imported both from India as well as from the European continent, in addition to those made at home both in the traditional way and by mechanized mills.

Again, the Dutch could point to unfair competition as the trade with British North America was restricted by the British Navigation Acts. However, that seems a feeble excuse as British trade with North America survived the end of mercantilism in North America. "Given the superiority and cheapness of British articles over those manufactured by the Dutch and the French, it is not surprising that some American merchants maintained contacts with British firms during the War of Independence and that British manufactured products were so much in demand in the USA."13

The two Atlantic products par excellence suffice to demonstrate this point: sugar and cotton. During the course of the eighteenth century, the consumption of sugar in Britain per head of the population increased far more rapidly than anywhere else in Europe, indicating a link with the process of industrialization. ${ }^{14}$ Compared to Britain, the consumption of sugar per head of the population in the Netherlands remained relatively low. Most sugar refined in the Netherlands was exported abroad. The production of, and the trade in, cotton is another indicator of economic modernization. To a disproportionate extent, the cultivation of cotton in the Dutch West Indies was in the hands of British planters. Cotton boomed during the British occupation of the colony (1798-1816), suggesting that this increase was a response to innovation in the British rather than in the Dutch economy because the traditional cotton mills in the Netherlands had moved away from the cities and were not expanding. ${ }^{15}$

13 Morgan, Slavery, Atlantic Trade and the British Economy, 66.

14 D. Richardson, "The Slave Trade, Sugar, and British Economic Growth, 1748-1776," Journal of Interdisciplinary History 17 (1987): 739-769.

15 Jan de Vries and Ad van der Woude, The First Modern Economy. Success, Failure, and Perseverance of the Dutch Economy, 1500-1815 (Cambridge: Cambridge University Press, 1997), 490-504, 385-389 (sugar); Stanley L. Engerman, "Mercantilism and Overseas Trade, 


\section{The Atlantic Influence on the Dutch Economy}

There have been a few attempts at calculating the volume of the Dutch share in the trade between Europe and the non-European world. Niels Steensgaard has suggested that the total value of all foreign imports into the Netherlands around the middle of the eighteenth century amounted to 150 million guilders, of which 20 to 25 percent came from non-European trade. No allowance had been made for the sale, re-export and distribution from, to and via the Netherlands of colonial imports and exports from and to the neighboring countries. Steensgaard calculated that around $175^{\circ}$ the share of the nonEuropean trade as a percentage of all trade in Britain was about 50 percent twice as much as for the Netherlands. ${ }^{16}$

A second difference between the Dutch and British trade patterns that the statistics of Steensgaard bring to light is the fact that within British colonial trade the importance of America versus Asia can be set at 3:1, while that ratio is roughly equal in the Dutch case. ${ }^{17}$ Only during the decade $1770-1779$ did the value of Dutch commodity imports from the West Indies exceed those from Asia. ${ }^{18}$

1700-180o," in The Economic History of Britain since 1 70o, ed. Roderick Floud and Donald McCloskey (Cambridge: Cambridge University Press, 1994, 2nd ed.), 187-194. The declining Dutch share in the trade in sugar during the eighteenth century is mentioned in Gérard Le Bouëdec, Activités maritimes et sociétés littorals de l'Europe atlantique, 1690-1790 (Paris: Armand Colin, 1997), 131-141. A discussion linking the rise of sugar consumption and industrialization is found in Kenneth Pomeranz, The Great Divergence. Europe, China, and the Making of the Modern World Economy (Princeton: Princeton University Press, 200o), 218, 274-275. The production and exportation of Surinamese cotton is discussed in Alex van Stipriaan, Surinaams contrast: Roofbouw en overleven in een Caraïbische plantagekolonie, 1750-1863 (Leiden: KITLV, 1993), 141, 201. These Dutch cotton exports show up as imports into Britain in Seymour Drescher, Econocide: British Slavery in the Era of Abolition (Pittsburgh: University of Pittsburgh Press, 1977), 57 (Table 12).

16 Niels Steensgaard, "The Growth and Composition of the Long-Distance Trade of England and the Dutch Republic before 1750," in The Rise of Merchant Empires: Long-Distance Trade in the Early Modern World, 1350-1750, ed. James D. Tracy (Cambridge: Cambridge University Press, 1990), 102-152.

17 Wim Klooster, Illicit Riches: The Dutch Trade in the Caribbean, 1648-1795 (PhD diss., Department of History, University of Leiden, 1995), 169-199; Victor Enthoven, "An Assessment of Dutch Transatlantic Commerce, 1585-1817," in Riches from Atlantic Commerce. Dutch Transatlantic Shipping and Trade, 1585-1817, ed. Johannes Postma and Victor Enthoven (Leiden/Boston, 2003), 385-445.

18 Jan de Vries, "The Dutch Atlantic Economies," in The Atlantic Economy during the Seventeenth and Eighteenth Centuries, ed. Peter A. Coclanis (Columbia, sc: University of South Carolina Press), 1-29. 
How important were those Asian and West Indian imports to the Dutch economy as a whole? The most recent calculations put the national income of the Netherlands around 1800 at about 300 million guilders, while the trade outside Europe earned the Dutch about 20 to 30 million guilders or about 10 percent of the total. ${ }^{19}$

These figures indicate that the Dutch economy of the ancien régime was more dependent on income from trade with other continents than virtually any other economy in Europe, perhaps with the exception of Portugal. Trade was certainly less important to the British economy as a whole than to the Netherlands. Yet, within the mercantile sector of the two countries, non-European trade, and especially trade in the Atlantic, was twice as important for Britain as for the Netherlands. That seems to confirm the assumption that shipping and trade in the Atlantic were less profitable for the Netherlands than for Britain. ${ }^{20}$

The economic histories of the Netherlands, Portugal, Spain and France are killing fields for anyone trying to link industrialization to foreign trade, let alone to Atlantic trade. England is the exception, but even for the economy of that country the contribution of income earned on trade outside Europe was modest at best, something in the order of the income derived from the economy of an average duchy in England. That seems to suggest that even for Britain, the most likely candidate country to have profited from the slave trade and slavery, the Industrial Revolution could not be directly linked to the increasing economic benefits derived from New World slavery. ${ }^{21}$ In all other countries with a stake in the Atlantic, industrialization took place when the Atlantic slave trade and slavery had been abolished.

Anyone looking for a link between the contribution of the colonies to the Dutch economy and industrialization will not point at the Atlantic, but at Java. Between 1840 and 1870 , the transfer payments generated by the forced cropping system ("cultivation system") on Java flowed into the public purse, and were used to increase government expenditure on the construction of waterways and of a new railroad system in the Netherlands. These transfer payments

19 Vries and Van der Woude, The First Modern Economy, 704-705.

20 Patrick K. O'Brien and Stanley L. Engerman, "Exports and Growth of the British Economy from the Glorious Revolution to the Peace of Amiens," in Slavery and the Rise of the Atlantic System, ed. Barbara L. Solow (Cambridge: Cambridge University Press, 1991), 177-209, 186; S. Engerman, "Mercantilism and Overseas Trade," 191-192 and Le Bouëdec, Activités maritimes, 151.

21 David Eltis and Stanley L. Engerman, "The Importance of Slavery and the Slave Trade to Industrializing Britain," Journal of Economic History 6o, no. 1 (March 2000): 123-144. 
reached their peak in the late 1850 s when they made up as much as 23 percent of the yearly income of the Dutch state. ${ }^{22}$

\section{Why the British in the Atlantic Moved Ahead and the Dutch Remained Behind}

In addition to the comparative decline in the productivity of Dutch shipping in the Atlantic and the Dutch preference to recruit migrants for Asia rather than for the Atlantic, there are three other features that made the Dutch Atlantic different from its British counterpart, and that impacted negatively on the profitability of the Dutch Atlantic.

The first deviation from the pattern of British activities in the Atlantic was the relatively large volume of the Dutch transit trade. Recent research has shown that the illegal trade to and from Spanish America, in addition to the transit trade to and from the French Caribbean, was worth more than the value produced in the Dutch plantation colonies. The Dutch preference for the trade rather than for production can be explained by the fact that it required much less investment. The drawback was, however, that the Dutch had no control over the volume, which differed widely from year to year, while the British colonies produced a steadily increasing volume of sugar, coffee and cotton. ${ }^{23}$

A second difference between the British and the Dutch experience pertains to the way in which both countries financed their West Indian activities. In the British case, there was a constant flow of investment money going to the plantations. Part of that money was the capital that a new planter took with him to the West Indies and another part was provided by merchant houses that specialized in the importation and sale of plantation produce, as they were used to advance loans and mortgages to their customers. Until 1750, the same pattern existed in the Dutch Caribbean, but, after that year, groups of Amsterdam investors suddenly started to offer large mortgages to West Indian planters in Suriname as well as in the British "Ceded Islands." As was the case elsewhere in Europe, Dutch investors moved away from buying government

22 For a broader discussion of the contribution of the non-European world to the growth of the economy of the colonial powers see Stanley L. Engerman, "The Atlantic Economy of the Eighteenth Century: Some Speculations on Economic Development in Britain, America, Africa and Elsewhere," Journal of European Economic History 24, no. 1 (Spring 1995): 145-175, especially $157-168$.

23 P.C. Emmer, O. Pétré-Grenouilleau and Jessica Vance Roitman, eds., $A$ 'Deus ex Machina' Revisited, 151-177 and Wim Klooster, Illicit Riches. 
bonds and other low-risk instruments of investment and started to put some of their money into high-risk "bubbles." In this case, the result was disastrous. The amount of mortgages provided to the Suriname planters far exceeded their ability to pay the interest on these mortgages, let alone to pay back the principal. After 1773, this situation resulted in a wave of bankruptcies, and soon the majority of the plantations were owned by the investment funds that had provided the loans and mortgages in the past. No wonder, then, that after the crash of the Amsterdam stock exchange the flow of new investment capital for the plantation colonies dropped dramatically, and this process of over- and under-investment severely hampered the expansion and modernization of the plantations. As a result, some areas of Dutch Guiana could only continue to grow due to the immigration of British planters with their slaves and capital. In addition to slowing down the development of new plantation areas in Suriname, the lack of credit also affected the established plantations. ${ }^{24}$

A third difference constituted the rapid decline of the Dutch slave trade and the dramatic growth of the British slave trade. In part, that difference can be explained by the way in which the slave traders were paid. In the British case, the bills came from the agents of the metropolitan merchant houses residing in the West Indies. This provided the British slave traders with much more security than their Dutch colleagues. "By comparison with their French and Dutch counterparts, the Liverpool slave traders appear to have been much more independent of colonial credit and relatively unencumbered with the heavy indebtedness of the plantation economy."25 In contrast, the Dutch slave trade suffered badly from the lack of new money for the Dutch plantations. Before the crash of the Amsterdam stock exchange, planters used bills of exchange drawn on the merchant houses cum mortgage providers in the Netherlands in order to pay for the slaves. That meant that slaving firms could obtain full payment for their slaves upon the return of the slave ship to its homeport. After the crash this method of payment came to a grinding halt, as most bills of exchange were no longer honored and, as a consequence, the shipping firms themselves were forced to collect the price of their slaves in cash or in kind from the planters. It sometimes took years and years before a slave cargo had been paid in full. That explains why, after the crash, and again

24 Gert Oostindie, "British Capital, Industry and Perseverance' versus Dutch 'Old School'?: The Dutch Atlantic and the Takeover of Berbice, Demerara and Essequibo, 1750-1815," BMGN - Low Countries Historical Review 127, no. 4 (2012): 28-55.

25 B.L. Anderson, "The Lancashire Bill System and its Liverpool Practitioners," in Trade and Transport; Essays in Economic History in Honour of T.S. Willan, ed. W.H. Chaloner and Barrie M. Ratcliffe (Manchester: Rowman and Littlefield 1977), 59-97, esp. 80. 
after the end of the Fourth Anglo-Dutch War in 1784, the Dutch slave trade declined rapidly, while the British slave trade (and that of most slave trading nations in the Atlantic) experienced a dramatic increase in volume. In order to survive at all, the Dutch slave trade had to be freed from all taxes and levies. ${ }^{26}$

In all fairness, however, the superior buying power of the planters in the British Caribbean must have also contributed to the remarkably high profits in the British slave trade. British planters had more buying power because they enjoyed incomes that were, in part, based on the protective tariffs for their sugar in the British home market. ${ }^{27}$ The British consumer not only bought much more sugar than any consumer on the Continent, but he or she also had to pay more for it than elsewhere. The figures are telling. In the 1720s, Britain re-exported about 20 percent of its sugar to foreign markets and, during the last quarter of the eighteenth century, this percentage had fallen to less than 5 percent. The planters in the Dutch West Indies, on the other hand, did not receive protection and had to compete with the most cost-effective producers anywhere, resulting in relatively low profits in the Dutch slave trade as well as in Dutch West Indian plantation agriculture. ${ }^{28}$

\section{Conclusion}

By comparing the Dutch expansion in Asia and the Atlantic, it seems selfevident that the constituent components of the successful Dutch policy in Asia produced a different, if not an opposite, effect in the Atlantic. A large monopoly company for all Dutch trade to and within Asia worked wonders,

26 The plantations loans have been studied by J.P. van de Voort, De Westindische plantages van 1720 tot 1795: financiën en handel (Eindhoven: Witte, 1973). For the British slave trade see Morgan, Slavery, Atlantic Trade and the British Economy, 1660-180o, 75.

27 Stanley L. Engerman, "British Imperialism in a Mercantilist Age, 1492-1849: Conceptual Issues and Empirical Problems," Revista de Historia Económica 16, no. 1 (1998): 195-231, especially 206-207, "Thus the protective provision of the Acts [of Navigation] led to some redistribution from British consumers to planters in the British West Indies."

28 Seymour Drescher, Econocide, 52-53; David Richardson, "Profits in the Liverpool Slave Trade: the accounts of William Davenport, 1757-1784," in Liverpool, the African Slave Trade, and Abolition. Essays to Illustrate Current Knowledge and Research, ed. Roger Anstey and P.E.H. Hair (Liverpool: Historic Society of Lincolnshire and Cheshire 1976), 6o-9o, 80 mentions a profit rate of 8 percent. That is more than double the rate of the Middelburgsche Commercie Compagnie operating between 1732 and 1803 according to Roger Anstey, The Atlantic Slave Trade and British Abolition, 1760-1810 (London: Macmillan 1974), 38-57, esp. 57 . 
but its sister company in the Atlantic was a failure. Similarly, the Dutch recruiting system for staffing its trading posts and ships in Asia was extremely successful, but not for peopling its Atlantic colonies. As far as trade between Europe and Asia is concerned, the Dutch might well have carried about half the total volume, in addition to which they had a sizeable trading network within Asia. In the Atlantic, on the other hand, the Dutch share in the transatlantic slave trade was about 5 percent and their share in other branches of trade in the Atlantic was perhaps somewhat higher.

In contrast to Asia, it was impossible to monopolize trade routes or the production of goods in the Atlantic. That is why legislation was needed to create protection. The trade between the European countries and their New World colonies was subject to protective legislation and even the champions of free trade, the Dutch, legislated that all goods and slaves imported or exported to and from the Dutch plantation colonies should be shipped on Dutch ships only. In actual practice, however, a part of the Atlantic trade was open to competition as the Portuguese, Spanish, and French merchants and shipping companies were not always able to provide shipping capacity, slaves, and trade goods in sufficient numbers and quantities at competitive prices. During the seventeenth century, the Dutch played an important part in providing the illegal tonnage, goods and slaves to third parties, but over time their competitive edge diminished dramatically as is shown by the declining volume of the Dutch slave trade to non-Dutch colonies. In the second half of the eighteenth century, when British, American and even Danish slave traders were successful in supplying Cuban planters with slaves when the island started to produce sugar in a large way, the Dutch were absent.

The same applies to migration. In Asia, the Dutch were extremely successful in attracting young men from all over Europe to serve in the Dutch East India Company. In the Atlantic, however, the Dutch hardly made an effort to find settlers for their colonies in the New World. Unlike the English, the number of indentured laborers migrating to the New World was very small; while the Dutch mercantile community did not seemed interested in financing "planting" ventures as was the case in England. After the loss of Dutch Brazil and Dutch North America, the Dutch no longer possessed suitable settlement colonies and the number of Dutch migrants settling in foreign colonies was negligible in the Atlantic.

The opposite seems to apply to Dutch investments in the Atlantic. The money available in the Netherlands for Atlantic ventures was larger than the demand in the Dutch Atlantic. That is why investment funds were organized that provided anonymous mortgages to planters both in the Dutch and non-Dutch Caribbean. In the case of the British, the investment in foreign 
colonies was not anonymous, but linked to British planters and merchants moving into French, Spanish or Dutch colonies.

And last but not least, the home economy should be considered. The size of the consumer market at home did not govern the volume of Asian imports as luxury goods could command a European-wide market. On average imports from Asia had a high value and a small volume, almost no value was added in Europe and the clientele was international. Most Asian goods might be auctioned in London or Amsterdam, but they traveled on to other parts of Europe and indeed to Africa and the New World.

The production, sale, and consumption of Atlantic goods, on the other hand, was, to a large extent, dominated by the boundaries of the various national compartments in the Atlantic in spite of smuggling and illegal trade documented in a growing number of studies. ${ }^{29}$ The fact that empire mattered, despite the permeability of imperial systems evidenced in the incorporation of "outsiders" like the Dutch within the French or Spanish systems as detailed in this volume by Silvia Marzagalli and Ana Crespo Solano, respectively, is a point brought home in the chapter by Christian Koot in this volume. Some parts of Spanish America seemed to have conducted more illegal than legal trade and all of the plantation colonies in the Caribbean were dependent upon the "Yankee traders" for the importation of certain victuals and the exportation of dram and molasses regardless of the confining laws of mercantilism. This dependency on North American traders is vividly highlighted in Karwan Fatah-Black's contribution to this book. He shows how necessary to Suriname the provisions provided by the North Americans were. Yet the majority of the imports and exports remained within the various national sections of the Atlantic, and the British section was the most successful one.

The British had the only Atlantic empire with a truly integrated economy, especially when we include Ireland. During the course of the seventeenth century England had developed its own manufacturing industry protected against foreign competition by the Navigation Acts and the same protection was granted to the sugar produced in the English Caribbean. Yet, towards the end of the eighteenth century, no country in the world consumed so much sugar per head of the population as Britain. Protection makes for high prices, but in the British Atlantic this was not an obstacle to growth. The inhabitants of

29 David R. Ringrose, Spain, Europe and the 'Spanish Miracle', 1700-1900 (Cambridge: Cambridge University Press, 1996) and Olivier Pétré-Grenouilleau, "Colonial Trade, And Economic Development in France, Seventeenth to the Twentieth Centuries" in A 'Deus ex Machina' Revisited. Atlantic Colonial Trade and European Development, ed. P.C. Emmer, O. Pétré-Grenouilleau and Jessica Vance Roitman, 225-261. 
Great Britain could afford high sugar prices as their country was the first to industrialize, providing higher per capita incomes. Industrialization also explains why higher wages do not necessarily result in higher prices for British exports as it increased the labor productivity dramatically. During the first decade of the nineteenth century, 54 percent of all manufactured goods in Britain were exported to the Americas, a figure that no other European country with an Atlantic empire could match even if we allow for the compensation effect as British exports to the Continent had declined because of the war with France. ${ }^{30}$

The Dutch Atlantic could never rival the British achievement for the simple reason that the market for Dutch exports in Africa and the New World was extremely small. That is why the Atlantic only had a very modest impact on the Dutch economy, while the buying power of the British settlement colonies was substantial. The first-ever population count in Great Britain held in 1801 revealed that the country had about 10 million inhabitants, while Ireland and the New World colonies (including the recently independent Us) counted more than 8 million inhabitants. ${ }^{31}$ The population of the Dutch Atlantic counted 2 million inhabitants in Europe and not even 100,00o in their Atlantic colonies, most of whom were slaves.

These figures seem to suggest that the Dutch responded to the Atlantic challenge by creating a trading empire, while the British not only created a trading empire but also an important market for their home industry. In addition to the usual imports of sugar, coffee and cotton, their Atlantic empire became a substantial outlet for British goods and services and in the nineteenth century came to include the newly independent parts of South America.

These facts indicate that over time the Dutch experience in the Atlantic deviated drastically from that of Britain, and, in order to explain this difference, this chapter has discussed several external and internal factors influencing the Dutch performance, showing that both external and internal factors were at play. That the Dutch were unable to hold on to one or more large-scale settlement colonies was due to an external factor: the lack of naval power. Even France, a much larger, a more powerful and more populous country than the Netherlands, lost its settlement colony in North America, albeit a century later than the Dutch. However, the declining Dutch share in the Atlantic trade was

30 Craig Muldrew, "Atlantic World 1760-1820," in The Oxford Handbook of the Atlantic World, C1450-C185o, ed. Nicholas Canny and Philip Morgan (Oxford and New York: Oxford University Press, 2011), 618-634, 627-631.

31 Carole Shammas, "Household Formation, Lineage, and Gender Relations in the Early Modern Atlantic World," in Oxford Handbook of the Atlantic World, $362-381,363$ (Table 21.1). 
caused by an internal factor: the relative decline in the productivity of Dutch trade and shipping. That is why the Dutch share in the trade in goods and slaves to non-Dutch colonies diminished relative to that of its competitors in areas where protective legislation hardly made the difference. It also explains as to why the Dutch were unable to profit commercially from the opening up of Latin America and relied heavily on protectionist legislation in order to prevent being outcompeted by British and us firms in the trade and shipping to their own colonies. Trade barriers, the much-hated stumbling block for Dutch expansion in the seventeenth century, had become a protective wall. Dutch commerce in the Atlantic had come full circle. 